\title{
Relação entre fala, tônus e praxia não-verbal do sistema estomatognático em pré-escolares****
}

\author{
Relationship between speech, tonus and non-verbal praxis of the \\ stomatognathic system in preschoolers
}

Samira Raquel de Farias*

Clara Regina Brandão de Ávila**

Marilena Manno Vieira**

*Fonoaudióloga. Mestre em Distúrbios da Comunicação Humana pela

Universidade Federal de São Paulo. Pesquisadora Voluntária do

Departamento de Fonoaudiologia da Universidade Federal de São Paulo. Endereço para correspondência: Rua Botucatu, 802 - São Paulo - SP - CEP 04023-900 (samirafarias@terra.com.br).

**Fonoaudióloga. Doutora em Distúrbios da Comunicação Humana pela Universidade Federal de São Paulo. Professor Adjunto Doutor do Departamento de Fonoaudiologia da Universidade de São Paulo.

***Trabalho Realizado na Universidade Federal de São Paulo.

Artigo de Pesquisa Artigo Submetido a Avaliação por Pares Conflito de Interesse: não

Recebido em 16.09.2005.

Revisado em 17.11.2005; 10.04.2006; 13.06.2006; 2.10.2006.

Aceito para Publicação em 26.10.2006.

\begin{abstract}
Background: relationship between speech, tonus and non-verbal praxis. Aim: to verify the relationship between speech, tonus and non-verbal praxis of the stomatognathic system in preschoolers. Method: 120 children, with ages between 4:0 and 5:11 years, were assessed. This assessment consisted of an anamnesis and a speech-language evaluation. The anamnesis was carried out with each child and was completed with information obtained through a questionnaire filled out by parents or guardians. The speech-language assessment involved: assessment of tonus (resistance), of mobility (execution of isolated movements), praxis of lips and tongue (repetition of sequential movements) and of speech (picture naming). Results: statistically significant findings were: normal tongue tonus in the group of children with normal praxis ( $\mathrm{p}=$ $\left.0.003^{*}\right)$; tongue with altered tonus in the group of children with altered praxis $\left(\mathrm{p}=0.003^{*}\right)$ and normal speech in the group of children with normal praxis $(\mathrm{p}<0.001)$. Other observations were: normal lip tonus in the group of children with normal praxis ( $\mathrm{p}=0.058$ ); altered speech (omission, substitution and distortion) in the group of children with altered lip tonus $(\mathrm{p}=0.149)$, normal speech in the group of children with normal tongue tonus ( $\mathrm{p}=0.332$ ); altered speech (omission, substitution and distortion) in the group of children with altered lip praxis $(\mathrm{p}=0.241)$. Differences in speech related to gender or age were not observed in the present study. However, children with ages between 4:0 and 4:11 years presented speech alterations in a higher proportion when compared to children with ages between 5:0 and 5:11 years. Conclusion: it was not possible to prove the existence of a relationship between tonus and lip praxis, and between lip praxis and speech. A relationship exists between tonus and non-verbal tongue praxis and also between non-verbal tongue praxis and speech.
\end{abstract}

Key Words: Articulation Disorders; Stomatognathic System; Preschool; Muscle Tonus.

\section{Resumo}

Tema: relação entre fala, tônus e praxia não-verbal. Objetivo: verificar a existência de relação entre fala, tônus e praxia não-verbal do sistema estomatognático em pré-escolares. Método: avaliamos 120 crianças, de 4:0 a 5:11 de idade. Todas foram submetidas à avaliação que constou de anamnese e avaliação fonoaudiológica. A anamnese foi realizada com a própria criança e complementada por informações obtidas por meio de um questionário, respondido por seus pais ou responsáveis. A avaliação fonoaudiológica constou de: avaliação do tônus (resistência), da mobilidade (realização de movimentos isolados), da praxia (repetição de movimentos seqüenciais) de lábios e de língua e da fala (nomeação de figuras). Resultados: os achados estatisticamente significantes foram: tônus de língua normal nas crianças do grupo de praxia normal ( $\mathrm{p}=$ $\left.0,003^{*}\right)$; tônus de língua alterado nas crianças do grupo de praxia alterada $\left(\mathrm{p}=0,003^{*}\right)$ e fala normal nas crianças do grupo com praxia normal ( $<<0,001)$. Observamos tônus de lábios normal nas crianças do grupo de praxia normal $(p=0,058)$, fala alterada (grupo omissão, substituição e distorção) nas crianças do grupo com tônus de lábios alterado $(\mathrm{p}=0,149)$, fala normal nas crianças do grupo com tônus de língua normal ( $\mathrm{p}$ = 0,332), fala alterada (grupo omissão, substituição e distorção) nas crianças do grupo com praxia de lábios alterada $(p=0,241)$. Neste estudo não foram observadas diferenças da fala em relação ao sexo ou a idade. Entretanto, as crianças de 4:0 a 4:11 anos apresentaram alterações de fala em maior proporção que as da faixa etária de 5 anos. Conclusão: não foi possível comprovar a existência de relação entre o tônus e a praxia de lábios, e entre a praxia de lábios e a fala. Constatamos a existência de relação entre o tônus e a praxia nãoverbal de língua e também entre a praxia não-verbal de língua e a fala.

Palavras-Chave: Transtornos da Articulação da Fala; Sistema Estomatognático; Pré-Escolar; Tônus Muscular.

Referenciar este material como:

FARIAS, S. R. de; ÁVILA, C. R. B. de; VIEIRA, M. M. Relationship between speech, tonus and non-verbal praxis of the stomatognathic system in preschoolers (original title: Relação entre fala, tônus e praxia não-verbal do sistema estomatognático em pré-escolares). Pró-Fono Revista de Atualização Científica, Barueri (SP), v. 18, n. 3, \3.267-276, set.-dez. 2006. 


\section{Introduction}

Speech is a complex function produced by central nervous system programming. The acquisition of phonemes has been widely studied and involves sound perception, organization and production (Oliveira and Wertzner, 2000; Wertzner and Oliveira, 2002).

Along the development the child perceives sounds (Wertzner et al, 2001) and presents, around 2:6 and 3 years of age, a clearly growing process of speech production. In this period the child improves oral articulatory movements and expands his/her vocal and linguistic universe. This way, between 3:0 and 6:0 years he/she can be understood inclusively by people outside his/her social group. Some ages are milestones in phoneme acquisition (Wertzner et al, 2001; Motta et al, 2003) and around five years all the phonological system should be established. Pagan and Wertzner (2002) describe in their studies that around six years substitutions, omissions or distortions are not expected to occur.

The correct speech sound production depends on motor or articulatory abilities and on precision and coordination of stomatognathic system's movements. Although children of 3:0 years are apt to correctly reproduce speech sounds (Douglas, 2002) this process not always occur in the expected way. Under the phonological point of view the child uses processes that simplify the sound system by means of omissions and substitutions during the speech acquisition and development process (BefiLopes e Palmieri, 2000; Wertzner and Patah, 2001).

In what refers to the production of sounds it is important to know, also, the structural and functional features of the speech articulators. Genetic, environmental and/or functional factors interfere on the growing and development of stomatognathic system (Felício et al, 2003). And the articulatory points' precision in influenced by the presence and position of tooth, lips and face mobility, position and mobility of tongue and jaw position, besides an intra-oral space adequate to the phonemic articulation and resonance (Bianchini et al, 2003).

It is known that children are not born with developed speech movements and therefore doesn't present developed praxis. Praxis is considered a functional learning - and not just the result of neuromotor maturation - and this way demanding interaction with speech production (Dewey, 1995).

In the beginning of development the motor speech control - that refers to the group of systems and strategies that control production (Kent, 2000) - is not totally established. Either the lack of articulatory precision as the larger variability of articulatory movements can be observed in small children (Clark et al, 2001). This variability is understood as the result of an important adaptative mechanism associated to organism development (Worhlert and Smith, 2002).

Considering praxis abilities, Meyer (2000) described that lips, tongue and jaw movements undergo changes and, from being undifferentiated movements in early childhood become refined and differentiated with development. These transformations are also fundamental to reach higher levels of articulatory precision and coordination, important to the oral communication effectiveness.

The increase of movements' precision and the development of lexical and cognitive abilities and of receptive and self-regulatory abilities result on intelligible speech system. Phonological acquisition interacts with speech motor control development in such a way that, to produce a sequence of sounds it is necessary that the child has the ability to activate the vocal tract and to order muscle movements in sequence (Milloy, 1997). Articulation praxis depends, this way, on the emergence of phonetic-phonological contrasts and on the ability to program and produce longer sequences of movements.

Praxic disorders may interfere on the sequence of movements necessary to speech sound production and on the production of non-verbal movement sequences. Discussions about diagnosis of these disorders are very common (Von Atzingen, 2002; Forrest, 2003).

Developmental speech apraxia also called development verbal dispraxia was described by Shriberg et al (1997) as a disorder on speech motor programming in which the child presents basically two characteristic features on their speech errors: they are different from the errors presented by children with delayed speech development and are similar to those presented by adults with acquired apraxia. According to Pereira et al (2003) speech apraxia is characterized by failure of muscle programming to sound production. That is, this disorder consists on the impairment on planning and execution of the movements necessary to speech sound articulation.

In a study to verify which are the criteria used to the diagnosis of developmental speech apraxia, 
Forrest (2003) observed diversity on the features described by 75 speech and language pathologists. Of the 50 mentioned features just six occurred in $51,5 \%$ of the answers provided by the participants: inconsistency of productions, oral motor inabilities, speech hesitations, inability to imitate sounds, increase of difficulties proportional to the increase in sentence length and difficulties to produce sound sequences.

The developmental speech apraxia's etiology is still not defined once it wasn't observed any neurological deficit caused by focal brain lesions in children that present speech disorders (Von Atzingen, 2002).

Non-verbal (oral) apraxia was described by Geng and Johnson (2003) as one of the disorders that affect the stomatognathic system impairing the coordination of non-verbal jaw, lip and tongue movements under command. According to the authors this disorder is different from the motor disorders of the stomatognathic system caused by hypotonia or orofacial muscle weakness.

Rodrigues (1999) investigated the praxic functions of the stomatognathic system and the performance on gestual imitation through a battery of tests aimed to assess lip, tongue and jaw praxis and other aimed to investigate superior limbs. The author had the objective to verify if children with articulatory disorders are different from normal children in praxic performance. He observed that stomatognathic system apraxia impairs facial mimic and imitation of lip and tongue gestures, eventually resulting in speech articulatory impairments.

Aram and Horwitz (1983) conducted a research aimed to verify if verbal apraxia was restricted to verbal tasks or if it involves a general sequencing disorder and if the verbal difficulties of apraxia are limited to speech or would occur also in non-verbal praxic functions (assessed through simple and complex voluntary oral non-verbal movements). All children had normal non-verbal intelligence, normal vocabulary and/or syntactic comprehension, inability or difficulty on the production of phonological sequences and moderate or severe speech motor disorder characterized by consonant and syllable omissions and metathesis errors in polysyllabic words. On the task of isolated movements execution, four $(40,0 \%)$ children produced the movement without difficulty, two (20,0\%) children presented moderate difficulty and four $(40,0 \%)$ presented moderately-severe difficulty. On the second task, which assessed the repetition of sequences of movements, two $(20,0 \%)$ children produced the movements correctly, one
(10,0\%) had moderate difficulty and seven (70,0\%) showed moderately-severe difficulties. The authors observed that four $(40,0 \%)$ children had worse performance on tasks that involved complex oral movements. This way, eight $(80,0 \%)$ of the ten children presented difficulty in the production of oral movements produced in sequence.

The literature states that some speech disorders frequent in children are associated with structural disorders and this way highlights the signs of development and the importance of oralfacial structures balance and of the coordination between articulatory, laryngeal and respiratory mechanisms to articulatory speech production (Kent, 2000; Tomé et al, 2001; Bianchini et al, 2003; Felício et al, 2003; Dang and Honda, 2004; Tomé et al, 2004).

The hypothesis that articulatory movements sequence acts on the speech development was tested by Green et al (2000) and by Green et al (2002), researching the coordination of lip and jaw to speech and the influence of speech motor development over the phonological system acquisition. This study didn't prove the interference of the physiological development effects over the phonological acquisition, although it has related immature articulatory coordination to the disorders of speech intelligibility early developed.

Phonological and phonetic-articulatory disorders - considered as tongue motor inabilities - were observed in children that presented difficulties with the production of the $/ \mathrm{r}$ / phoneme, showing a relationship between the production of this sound and tongue praxis (Rigatti et al, 2001; Fonseca et al, 2003).

The diagnosis of speech disorder without language disorder in children is frequent although there are still disagreement about the causes and symptoms of these disorders. Speech pathology clinical practice still needs more precise and objective diagnostic protocols that assess the stomatognathic system, especially in what refers to praxis. There are still no validated protocols or determined normalcy criteria. Fast, simple and easy to apply methods would allow correct diagnosis and efficient therapy.

We will focus in this work only the assessment of the execution of non-verbal movements, that is, lip and tongue praxis ability on movements not destined to the speech sound production. But we will investigate the possible relationship between speech, tonus and praxis using Rodrigues' (1999) protocol to the evaluation. This is a partial study 
and we will present the results of only three of the eight tasks proposed by Rodrigues (1999) to the evaluation of the stomatognathic system.

Aiming further information about the issue we conducted this work with the objective to verify the existence of relationship between speech, tonus and non-verbal praxis of the stomatognathic system in preschool children.

\section{Method}

This study was approved by the institution's ethic and research committee (UNIFESP/EPM 1478/03). Information was gathered after the parents or other responsible adults signed the consent form allowing the realization of this research and the publication of its results, according to Resolution 196/96 (BRASIL. Resolution MS/CNS/CNEP n ${ }^{\circ}$ 196/96, 10/10/1996).

Were evaluated 120 children (58.3\% female) with ages varying between 4:0 and 5:11 years, Brazilian Portuguese speakers, attending regular public and private schools of the city of Sao Paulo.

There weren't included on the sample preschoolers with general or specific motor disorders and/or children with complaints or evidence of hearing impairment, mental retardation, congenital syndromes or malformations, structural disorders, children with disorders of lip and tongue mobility and those that failed on naming task (didn’t name items), showing language disorders. Also were excluded children whose history included signs of disorders on motor, hearing or language acquisition and/or development or that were attending or had attended speech and language pathology.

Dental occlusion or tooth conservation status were not considered.

All children of the sample were submitted to interview and speech and language evaluation. Identification data (name, age, gender and grade) were obtained with the children. Interview was completed with parents or responsible adults using a questionnaire with questions about pregnancy, delivery, motor, language and speech development and about hearing (otytis and hearing loss complaints).

Speech evaluation included the exam of lip and tongue about tonus, mobility and non-verbal praxis and assessment of speech.

During evaluation, conducted in the school each child remained seated with upper body placed vertically to the horizontal plan and head oriented to the Frankfurt plan and the central medium plan perpendicular to the horizontal plan. The procedures were conducted within bio-security rules.

To assess lip tonus we used part of the muscle function tasks (Daniels and Worthingham, 1996). The child was instructed to press and protrude the lips, pressing them against a spatula firmly held diagonally by the researcher. Lips tonus was classified as Normal (adequate resistance to pressure on the spatula) or Altered (decreased resistance).

To evaluate tongue tonus the child was asked to remain with the mouth opened, protrude the tongue without touching the lips or teeth and then contrary press the spatula firmly held by the researcher (Daniels and Worthigham, 1996). Tongue tonus was classified as Normal (adequate resistance to pressure on the spatula) or Altered (decreased resistance).

Lip and tongue mobility was evaluated through simple and isolated movements prompted by verbal command and model provided by the examiner. The mobility exam preceded the praxis evaluation because lip and tongue mobility disorder may interfere on the performance on tasks of praxis. Lip mobility was evaluated through isolated movements of protrusion and contraction. The child was asked to produce the movement only once. Tongue mobility was evaluated through the execution of isolated movements of elevating, bringing down, and lateralizing the tip of the tongue outside the mouth, only once.

Non-verbal praxis was evaluated with lip and tongue movement tasks proposed by Rodrigues (1999). Time was measured with a chronometer Taksun TS*613 ${ }^{\text {A }}$. Lip praxis was examined by the observation of sequences of alternate movements of protrusion and contraction prompted by verbal command by the examiner. It was asked that the sequence of movements was repeated several times. In this task the child had only one chance to execute the sequence of movements (Rodrigues, 1999). Lip praxis was described as: Normal (five repetitions of sequences of the two movements asked - protrusion and contraction - correctly performed in less than five seconds) or Disordered (the child didn't produce correctly the five repetitions of the movement sequences, or executed them, but took more than five seconds to make it).

To the exam of tongue non-verbal praxis two tasks were used: the first task evaluated the execution of a sequence of up and down movements and the second evaluated the execution 
of a sequence of lateralization movements, interspersed with elevation movements.

To produce up and down movements the child was oriented to keep the mouth opened and bring the tip of the tongue up and down touching the medium line of the superior and inferior lip. The model was provided by the examiner who produced the movements along with the child. Five repetitions of the up and down tip tongue sequences were asked. Praxis was classified as: Normal (five repetitions of sequences of the two movements asked correctly performed in less than five seconds) or Disordered (the child didn't produce correctly the five repetitions of the movement sequences, or executed them, but took more than five seconds to make it).

To the second task the child should keep the mouth opened and produce lateralization movements to the right and left interspersed with elevation movements. The child was oriented to lateralize the tip of the tongue to touch the right and left lip comissure's and then touch the medium line of the upper lip, keeping the sequence. The examiner showed the movements, didn't produce them along with the child and asked for five sequences of lateralization movements interspersed with tongue elevation movement. When the child couldn't execute them or changed the realization sequence a second chance was given (Rodrigues, 1999). This way, if the child didn't execute correctly the five repetitions of the sequence of movements in 10 seconds or did it correctly but in more than 10 seconds, the movements could be produced once again. Nonverbal praxis was described as: Normal (the child correctly produced five repetitions of sequences of the movements asked in less than 10 seconds in one of the trials) or Disordered (the child didn't produce correctly the five repetitions of the movement sequences, or executed them, but took more than 10 seconds to make it in both trials).

The correct realization of the movements sequence and the time taken to execute them were considered to classify tongue non-verbal praxis as: Normal (the sequence of movements repetition was considered normal in the first and in the second task) or Disordered (the repetition of the sequence of movements was classified as disordered in the first or the second or in both tasks).

The speech assessment was conducted through the observation of spontaneous talk during the interview done with the child and the picture labeling task that examines the speech disorders proposed by Yavas et al (1991). In this task thematic cards were shown to the child and he/she was asked to label the selected pictures.

The identification of speech disorders was based on the auditory perceptual analysis by the researcher and on the visual inspection of the tongue movements during evaluation. Picture labeling was phonetically recorded on a protocol and omissions, substitutions and distortions were registered to posterior analysis.

Speech disorders were classified as:

1. Distortion, also described aslisp, was characterized by the production of the phonemes / $\mathrm{s} /$ and /z/ with tongue projection to frontal and/or lateral regions of the dental arcs, associated or not to tongue interposition in the phonemes $/ \mathrm{t} / \mathrm{,} / \mathrm{d} / \mathrm{,}$ / $\mathrm{n} /$ and $/ \mathrm{l} /$.

2. Substitution, characterized by the observation of sound switching in speech production, occurring when the child switches or sound by another.

3. Omission, characterized by the observed lack of the production of some sound, that is, it occurred when a given phoneme wasn't produced nor substituted by any other.

In this study the speech was classified as: Normal (produced without any articulatory impairment) or Disorderd (when produced with any of the disorders described).

\section{Statistical method}

In this work we used the Q-Square, a nonparametric test, to verify if two qualitative variables and their levels had statistical association (dependency) or not.

All association results on the Q-Square will be presented in tables that bring the group distribution of two variables in absolute and percentile values. The significance level considered was 0,05 (5\%). The p-values considered statistically significant to the adopted significance levels will be highlighted by (*) and the p-values next to the acceptation threshold with tendencies to be significant will be signalized by (\#).

The totals placed in lines and columns are what we call Marginal Distribution. The percentile values express the percentage of each answering level in relationship to the total sample. This way we have what is called in statistics the Marginal Distribution of variables. 


\section{Results}

In the study of the relationship between lip tonus and non-verbal praxis in preschoolers (table 1) we observed normal tonus in children of the group with normal praxis $(68,4 \%)$ and disordered tonus in 13 children of the group with disordered praxis (52,0\%).

When analyzing the study of the relationship between tongue tonus and non-verbal praxis in children (Table 2) we observed as statistically significant findings: normal tonus in 38 children of the group with normal praxis $(74,5 \%)$ and disordered tongue tonus in 36 children of the group with disordered praxis (52,2\%).

Observing the study of the relationship between speech and lip tonus (Table 3) we didn't find any statistically significant data. The most frequent findings were normal speech (GFN) in 23 children of the group with normal tonus (29,9\%) and disordered speech (GOSD) in 15 children of the group with disordered tonus (34,9\%).

Statistically significant findings also were not observed when relating speech and tongue tonus (Table 4) in the children of this study. We can point out as most frequent findings: normal speech (GFN) in 22 children with normal tonus (31,0\%) and disordered speech (GD) and (GOSD) in 14 children of the group with disordered tongue tonus (28,6\%).

When studying the relationship between speech and lip non-verbal praxis (Table 5) we observed as significant findings, the most frequently observed results: normal speech (GFN) in 26 children of the group with normal praxis $(27,4 \%)$ and disordered speech (GOSD) in 10 children of the group with disordered praxis $(40,0 \%)$, although they are not statistically significant.

In the study of the relationship between speech and non-verbal tongue praxis (Table 6) according to the group the statistically significant findings were disordered speech (GOSD) in 25 children of the group with disordered praxis and normal speech (GFN) in 25 participants of the group with normal praxis $(49,0 \%)$.

In the study of preschoolers' speech according to gender and speech group (Table 7) we didn't observe statistically significant relationships between the results. The most frequent findings were disordered speech (GOSD) in 16 boys (53,3\%) and disordered speech (GOS) in 20 of the girls (66,7\%).

About the study of children's speech according to age and group (Table8) the most frequent findings were disordered speech (GOSD) in 22 children with four years of age $(73,3 \%)$ and disordered speech (GOS) in 15 children with five years of age (50,0\%). Statistically significant data were not obtained although we observed significant difference between the number of children with speech disorder (GOSD) with four $(73,3 \%)$ and with five years of age $(26,7 \%)$.

TABLE 01. Relationship between lip tonus and non-verbal praxis in preschoolers.

\begin{tabular}{|c|c|c|c|c|c|c|}
\hline \multirow{3}{*}{ Tônus } & \multicolumn{4}{|c|}{ Praxis } & & \\
\hline & \multicolumn{2}{|c|}{ Normal } & \multicolumn{2}{|c|}{ Disordered } & \multicolumn{2}{|c|}{ Total } \\
\hline & $\mathrm{N}$ & $\%$ & $\mathrm{~N}$ & $\%$ & $\mathrm{~N}$ & $\%$ \\
\hline Normal & 65 & 68,4 & 12 & 48,0 & 77 & 64,2 \\
\hline Disordered & 30 & 31,6 & 13 & 52,0 & 43 & 35,8 \\
\hline Total & 95 & 79,2 & 25 & 20,8 & 120 & 100,0 \\
\hline
\end{tabular}


TABLE 02. Relationship between tongue tonus and non-verbal praxis in preschoolers.

\begin{tabular}{|c|c|c|c|c|c|c|}
\hline \multirow{3}{*}{ Tonus } & \multicolumn{4}{|c|}{ Praxis } & & \\
\hline & \multicolumn{2}{|c|}{ Normal } & \multicolumn{2}{|c|}{ Disordered } & \multicolumn{2}{|c|}{ Total } \\
\hline & $\mathrm{N}$ & $\%$ & $\mathrm{~N}$ & $\%$ & $\mathrm{~N}$ & $\%$ \\
\hline Normal & 38 & 74,5 & 33 & 47,8 & 71 & 59,2 \\
\hline Disordered & 13 & 25,5 & 36 & 52,2 & 49 & 40,8 \\
\hline Total & 51 & 42,5 & 69 & 57,5 & 120 & 100,0 \\
\hline
\end{tabular}

TABLE 03. Relationship between speech and lip tonus in preschoolers according to the group.

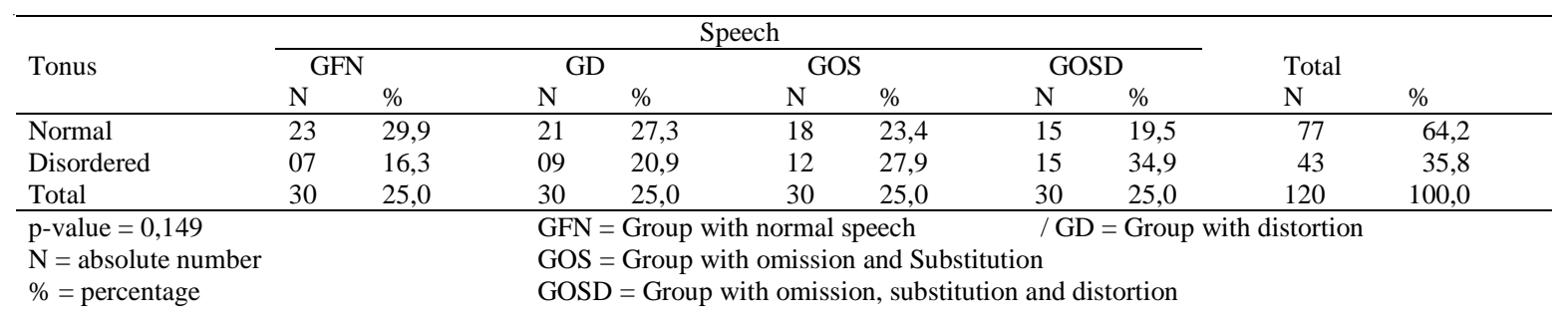

TABLE 04. Relationship between speech and tongue tonus in preschoolers according to the group.

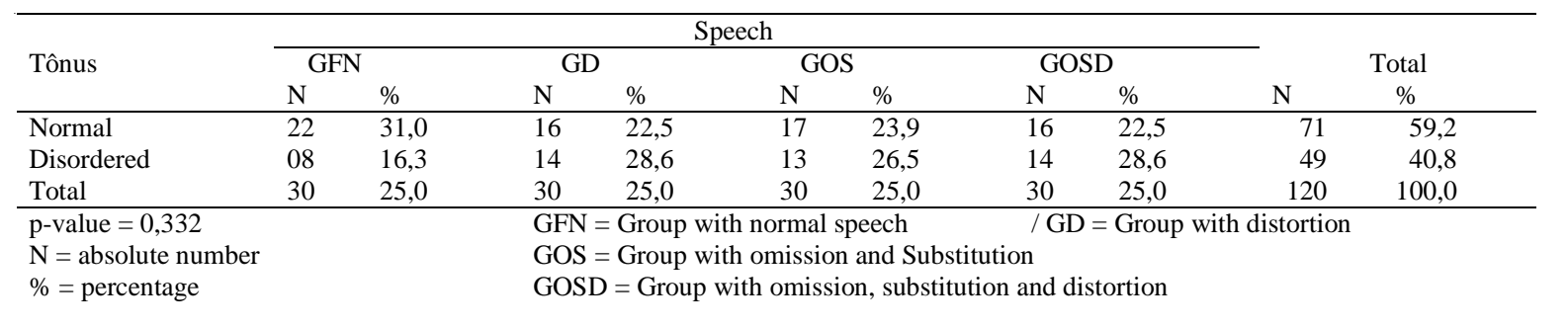

TABLE 05. Relationship between speech and lip non-verbal praxis in preschoolers according to the group.

\begin{tabular}{|c|c|c|c|c|c|c|c|c|c|c|}
\hline \multirow{3}{*}{ Práxis } & \multicolumn{8}{|c|}{ Speech } & \multirow{2}{*}{\multicolumn{2}{|c|}{ Total }} \\
\hline & \multicolumn{2}{|c|}{ GFN } & \multicolumn{2}{|c|}{ GD } & \multicolumn{2}{|c|}{ GOS } & \multicolumn{2}{|c|}{ GOSD } & & \\
\hline & $\mathrm{N}$ & $\%$ & $\mathrm{~N}$ & $\%$ & $\mathrm{~N}$ & $\%$ & $\mathrm{~N}$ & $\%$ & $\mathrm{~N}$ & $\%$ \\
\hline Normal & 26 & 27,4 & 24 & 25,3 & 25 & 26,3 & 20 & 21,1 & 95 & 79,2 \\
\hline Disordered & 04 & 16,0 & 06 & 24,0 & 05 & 20,0 & 10 & 40,0 & 25 & 20,8 \\
\hline Total & 30 & 25,0 & 30 & 25,0 & 30 & 25,0 & 30 & 25,0 & 120 & 100,0 \\
\hline $\mathrm{p}$-value $=0,241$ & & & \multicolumn{8}{|c|}{ GFN = Group with normal speech $\quad$ / GD = Group with distortion } \\
\hline $\mathrm{N}=$ absolute number & & & \multicolumn{8}{|c|}{ GOS = Group with omission and Substitution } \\
\hline$\%=$ percentage & & & \multicolumn{8}{|c|}{ GOSD = Group with omission, substitution and distortion } \\
\hline
\end{tabular}


TABELA 6. Relação entre a fala e a praxia não-verbal de língua nos pré-escolares segundo o grupo.

\begin{tabular}{|c|c|c|c|c|c|c|c|c|c|c|}
\hline \multirow{3}{*}{$\begin{array}{c}\text { P r a x i a } \\
N \text { ã o - } \\
\text { V e r b a l }\end{array}$} & \multicolumn{8}{|c|}{$\mathrm{F}$ a la } & \multirow{2}{*}{\multicolumn{2}{|c|}{$\mathrm{T}$ o t a $\mathrm{l}$}} \\
\hline & \multicolumn{2}{|c|}{ G F N } & \multicolumn{2}{|c|}{ G D } & \multicolumn{2}{|c|}{ G O $\mathrm{S}$} & \multicolumn{2}{|c|}{ G O S D } & & \\
\hline & $\mathrm{N}$ & $\%$ & $\mathrm{~N}$ & $\%$ & $\mathrm{~N}$ & $\%$ & $\mathrm{~N}$ & $\%$ & $\mathrm{~N}$ & $\%$ \\
\hline 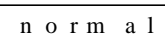 & 25 & 49,0 & 11 & 21,6 & 10 & 19,6 & 05 & 09,8 & 51 & 42,5 \\
\hline a $l$ te r a d a & 05 & 07,2 & 19 & 27,3 & 20 & 29,0 & 25 & 36,2 & 69 & 57,5 \\
\hline $\mathrm{T} \quad \mathrm{O} \quad \mathrm{T} A \mathrm{~L}$ & 30 & 25,0 & 30 & 25,0 & 30 & 25,0 & 30 & 25,0 & 120 & $\begin{array}{lll}1 & 0 & 0,0\end{array}$ \\
\hline
\end{tabular}

P-valor < 0,001*; GFN = grupo fala normal; GD = grupo distorção; GOS = grupo omissão e substituição; GOSD = grupo omissão, substituição e distorção; $\mathrm{N}=$ número absoluto; \% = porcentagem.

TABLE 07. Study of preschoolers' speech according to gender and group.

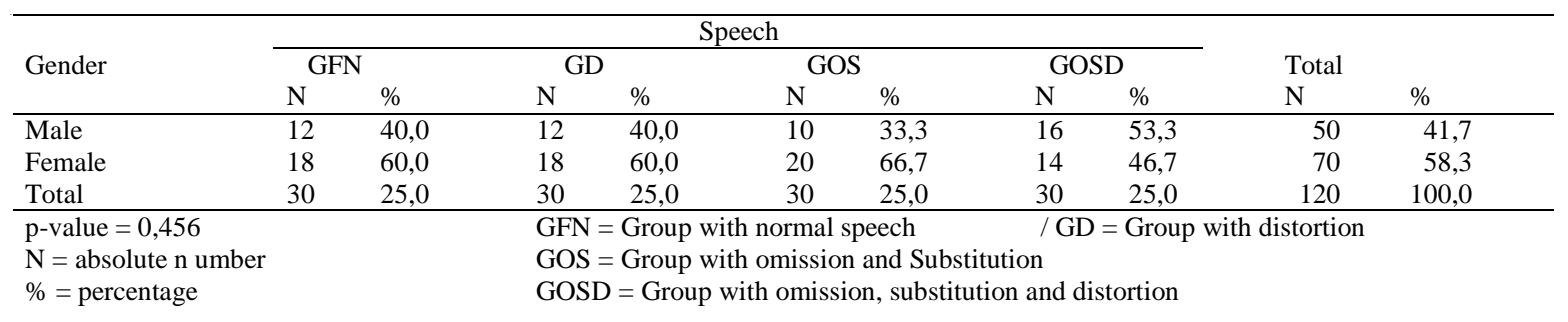

TABLE 08. Study of preschoolers' speech according to age and group.

\begin{tabular}{|c|c|c|c|c|c|c|c|c|c|c|}
\hline \multirow{3}{*}{ Age } & \multicolumn{8}{|c|}{ Speech } & \multirow{3}{*}{$\begin{array}{l}\text { Total } \\
\text { N }\end{array}$} & \multirow[b]{3}{*}{$\%$} \\
\hline & \multicolumn{2}{|c|}{ GFN } & \multicolumn{2}{|c|}{ GD } & \multicolumn{2}{|c|}{ GOS } & \multicolumn{2}{|c|}{ GOSD } & & \\
\hline & $\mathrm{N}$ & $\%$ & $\mathrm{~N}$ & $\%$ & $\mathrm{~N}$ & $\%$ & $\mathrm{~N}$ & $\%$ & & \\
\hline $4: 0 y-4: 11 y$ & 15 & 50,0 & 17 & 56,7 & 15 & 50,0 & 22 & 73,3 & 69 & 57,5 \\
\hline $5: 0 y-5: 11 y$ & 15 & 50,0 & 13 & 43,3 & 15 & 50,0 & 08 & 26,7 & 51 & 42,5 \\
\hline Total & 30 & 25,0 & 30 & 25,0 & 30 & 25,0 & 30 & 25,0 & 120 & 100,0 \\
\hline $\mathrm{p}$-value $=0,215$ & \multicolumn{10}{|c|}{ GFN = Group with normal speech $\quad$ / GD = Group with distortion } \\
\hline $\mathrm{N}=$ absolute number & \multicolumn{10}{|c|}{ GOS = Group with omission and Substitution } \\
\hline$\%=$ percentage & \multicolumn{10}{|c|}{ GOSD = Group with omission, substitution and distortion } \\
\hline
\end{tabular}

\section{Discussion}

To achieve the aim of verifying the existence of relationship between speech and lips and tongue tonus and non-verbal praxis in preschoolers initially lips and tongue tonus and mobility were assessed, considering that tonus and mobility impairment could interfere on praxis assessment.

Lips and tongue contraction power have been studied by other researchers (Mota and Guedes, 2000; Santos et al, 2000). Also, the realization of verbal and non-verbal, simple and sequenced movements by lips and tongue have been the investigative background to several scientific works (Aram and Horwitz, 1983; Meyer, 2000; Mota and Guedes, 2000; Santos et al, 2000; Bianchini et al, 2003; Felício et al, 2003; Fonseca et al, 2003).

When studying the existing relationship between tongue tonus and non-verbal praxis statistically significant results were obtained, showing that there may be a relationship between tongue tonus and non-verbal praxis in preschoolers, suggesting that muscle condition may interfere on the production of sequences of tongue movements. Despite literature points out that the presence of tonus disorder, as oral muscle 
hipotonia, characterizes an Oral Motor Disorder that is different from non-verbal apraxia (Geng and Johnson, 2003), we could observe in this research that tongue tonus disorder may interfere on the production of mobility exercises and therefore on the execution of praxis tasks, impairing the children's performances on non-verbal praxis tasks, showing the importance of assessing tongue tonus and non-verbal praxis.

Aram and Horwitz (1983) and Geng and Johnson (2003) had already mentioned the sequential prompted production of tongue protrusion and retraction, up, down and lateralization movements, among others, to assess oral praxis of children.

Other statistically significant result was observed when we studied the existing relationship between lips' non-verbal praxis and speech on the participant children. This data was obtained through speech assessment, by the identification of four groups of children, classified according to the types of disorders observed. Each group was formed by 30 preschoolers: Normal Speech Group (GFN): composed by children with normal speech. Distortion Group (GD): composed by children with systematic or as asystematic speech distortions, characterized by tongue projection during production of the phonemes $/ \mathrm{s} /$ and $/ \mathrm{z} /$, associated or not to the production of the phonemes /t/, /d/, / $\mathrm{n} /$ and /l/ with tongue interposition. Omission and Substitution Group (GOS): composed by the participants that presented omission or substitution of phonemes. Omission, Substitution and Distortion Group (GOSD): composed by children that presented either omissions and substitutions or distortions of phonemes, that means, phonetic and phonological disorders with speech production simplification associated to tongue projection. These groups were obtained after speech assessment through picture labeling.

In clinical practice labeling tasks have been widely used to assess speech because it guarantee the possibility of comparing children's performances (Yavas et al, 1991; Befi-Lopes and Palmieri, 2000; Mota and Guedes, 2000; Santos et al, 2000; Tomé et al, 2001; Wertzner and Patah, 2001; Wertzner and Oliveira, 2002; Bianchini et al, 2003; Felício et al, 2003; Fonseca et al, 2003; Tomé et al, 2004; Wertzner et al, 2004).

Our findings are statistically significant and show the influence of tongue praxis on the speech sounds production as well as the studies conducted by Aram and Horwitz (1983), Rodrigues (1999) and Rigatti et al (2001).
Actually problems on lips and tongue movements coordination may result in articulatory difficulties as described by Rodrigues (1999), Green et al (2000), Meyer (2000), Rigatti et al (2001), Green et al (2002) and Fonseca et al (2003). We verified that, despite we assessed non-verbal praxis, that means, the ability to produce non-verbal movements in sequence, there was a relationship between difficulties to coordinate movements non related to sound production and speech production itself. It suggests that even non-verbal praxic movements interfered on speech sound production.

Franco and Ávila (2000) verified that muscle tonus disorder, in general, was the most frequent speech pathology finding (73.3\%) when they studied the speech pathology findings of 30 patients with speech disorders. But the authors didn't specify if the observed disorders referred to lip, tongue and/or face tonus.

Other studies about the study of the relationship between speech and lip tonus, speech and tongue tonus, speech and lips praxis speech according to gender and age, didn't show statistical significance. Despite that, we observed a decrease on the number of speech disorders with increasing age. Children with age of four years presented more omissions and substitutions, and also distortions when compared to five year olds.

About omissions and substitutions the findings show what described on the literature: that at this age there is improvement on the acquisition of the phonological system (Oliveira and Wertzner, 2000; Wertzner et al, 2001; Pagan and Wertzner, 2002; Wertzner and Oliveira, 2002; Wertzner et al, 2004) associated to maturation of stomatognathic structures and functions, as we could observe in the works by Santos et al (2000), Felício et al (2003). But these results disagree with the ones presented by Mota and Guedes (2000).

The omissions most frequently observed in speech assessment conducted in this study were: reduction of consonantal blending and erasing of intervocalic liquid. The most common substitutions were: devoicing, anteriorization, liquid substitution and plosivation.

Felício et al (2003) mentioned the substitutions of phonemes groups by isolated phonemes, of voiced sounds by devoiced ones, of velar fricatives by palatal ones and oral-lateral distortions as the phonological processes more frequently observed in their research.

Franco and Ávila (2000) observed the presence of omissions, substitutions and distortion of 
sounds of the phonemic chart respectively on $80,0 \%, 86,7 \%$ and $43,3 \%$ of the children, showing that there is agreement as to the presence of omissions and phoneme substitutions.

In our study we also observed that distortion - that is,lisp, present when the tip of the tongue is protruded between the upper and lower incisive teeth (Honová et al, 2003) - associated or not to omissions and substitution showed decreasing frequency with increasing age. The same was described by Pereira et al (2003) when they concluded that the occurence of distortion (lisping) tend to decrease with age.

Mota and Guedes (2000), by their turn, didn't find decrease on the number of children with frontallisp when comparing preschoolers of four, five and six years of age. On the same way Tomé et al (2004) observed a statistically significant occurrence oflisp on children between four and five years when assessed children between three and six years of age.

Still about distortion, Wertzner et al (2005) assessed children with and without phonological impairment and observed that this was the most common disorder on both groups and that the children of the research group presented large variability of distortions because they didn't have the phonological system completely established.

In relationship to age and gender the results differed from those of Franco and Ávila (2000), Santos et al (2000), Tomé et al (2001), Wertzner and Oliveira (2002) and Tomé et al (2004) that observed higher number of speech disorders in boys.
Concluding, it can be mentioned the importance of assessing tongue's praxic abilities in preschoolers with speech disorders, specially those characterized by phoneme omissions, substitutions and distortions. Tongue praxis has been shown to interfere on speech and the diagnosis of these disorders, which had been shown easy to determine, may contribute to the therapeutic planning, suggesting that the praxic abilities exercise may minimize the speech disorders.

New research relating tonus and praxis of stomatognathic system's structures and speech should be developed because in this study tonus and praxis disorders have been shown to interfere on the speech sounds production.

\section{Conclusion}

Based on the findings of this study we believe we can conclude that it was not possible to prove the relationship between tonus and non-verbal lips' praxis. We also didn't identify any relationship between lips' praxis and speech. We found the existence between tonus and non-verbal tongue praxis. The relationship between tongue praxis and speech was also proved. The most frequent findings were: normal tonus in the group of children with normal non-verbal praxis $(74,5 \%)$; tongue tonus disorder in children of the group with non verbal praxis disorder (53,2\%); normal non-verbal praxis in children with normal speech (49,0\%).

\section{References}

ARAM, D. M.; HORWITZ, S. J. Sequential and non-speech praxic abilities in developmental verbal apraxia. Develop Med Child Neurol., London, v. 25, n. 2, p. 197-206, apr. 1983.

BEFI-LOPES, D.; PALMIERI, T. M. Análise dos processos fonológicos utilizados por crianças com alteração do desenvolvimento da linguagem. J. Bras. Fonoaudiol., Curitiba, v. 4, n. 4, p. 48-58, set.-dez. 2000.

BIANCHINI, E. M. G.; COSTA, A. V. R.; MOREIRA, C. O.; FADDEN, C. L. M.; OLIVEIRA, G. C. Verificação dos aspectos miofuncionais e produção do [s] em crianças de 5 a 6 anos. In: CONGRESSO INTERNACIONAL, 5., CONGRESSO BRASILEIRO, 11., ENCONTRO CEARENSE DE FONOAUDIOLOGIA, 1., 2003, Fortaleza. Anais... São Paulo: Sociedade Brasileira de Fonoaudiologia, out. 2003. p. 929. CD-ROM.

CLARK, H. M.; ROBIN, D. A.; MacCUllaGH, G.; SCMIDT, R. A. Motor control in children and adults during a non-speech oral task. J. Speech Lang. Hear. Res.,
Rockville, v. 44, n. 5, p. 1015-1025, oct. 2001.

DANG, J.; HONDA, K. Construction and control of a physiological articulatory model. J. Acoust. Soc. Am., New York, v. 115, n. 2, p. 853-870, feb. 2004.

DANIELS, L.; WORTHIGHAM, C. Provas de função muscular: técnicas de exame manual. 6. ed. Rio de Janeiro: Guanabara Koogan, 1996.

DEWEY, D. What is developmenatl dyspraxia? Brain Cognit., New York, v. 29, n. 3, p. 254-274, dec. 1995.

DOUGLAS, C. R. Tratado de fisiologia aplicada à saúde. São Paulo: Robe Editorial, 2002.

FELÍCIO, C. M.; FERREIRA-JERONYMO, R. R.; FERRIOLLI, B. H. V. M.; FREITAS, R. L. R. G. Análise da associação entre sucção, condições miofuncionais orais e fala. Pró-Fono R. Atual. Cient., Barueri (SP), v. 15, n. 1, p. 31-40, jan.-abr. 2003.

FONSECA, R. P.; DORNELLES, S.; RAMOS, A. P. F. Relação entre a produção do $r$-fraco e as praxias linguais 
na infância. Pró-Fono R. Atual. Cient., Barueri (SP), v. 15, n. 3, p. 229-240, set.-dez. 2003.

FORREST, K. Diagnostic criteria of developmental apraxia of speech used by clinical speech-language pathologists. Am. J. Speech-Lang. Pathol., Rockville, v. 2, n. 3, p. 378-380, aug. 2003.

FRANCO, R.; ÁVILA, C. R. B. Achados fonoaudiológicos de crianças com queixa de distúrbios de fala. Pró-Fono R. Atual. Cient., Carapicuíba (SP), v. 12, n. 1, p. 41-47, mar. 2000.

GENG, L.; JOHNSON, S. R. Diagnosis destinations: apraxia. [S.l.]: Speechville Express Routes, 2003. Disponível em: <URL:http://www.peech-express.com/diagnosisdestinations/apraxia/oral-apraxia.html.28k-26Feb2003>. Acesso em: 06 abr. 2006.

GREEN, J. R.; MOORE, C. A.; HIGASHIKAWA, M.; STEEVE, R. W. The physiologic development of speech motor control: lip and jaw coordination. J. Speech Lang. Hear. Res., Rockville, v. 43, n. 1, p. 239-255, feb. 2000.

GREEN, J. R.; MOORE, C. A.; REILLY, K. J. The sequential development of jaw and lip control for speech. J. Speech Lang. Hear. Res., Rockville, v. 45, n. 1, p. 66-79, feb. 2002.

HONOVÁ, J.; JINDRA, P.; PÉSAK, J. Analysis of articulation of fricative praealveolar sibilant "s" in control populations. Biomed. Pap. Med., Prague, v. 147, n. 2, p. 239-242, dec. 2003.

KENT, R. D. Research on speech motor control and its disorders: a review and prospective. J. Commun. Disord., Amsterdam, v. 33, n. 5, p. 391-428, sep-oct. 2000.

MEYER, P. G. Tongue lip and jaw differentiation and its relationship to orofacial myofunctional treatment. Int. J. Orofac. Myol., Seatle, v. 26, p. 44-52, nov. 2000.

Milloy, R. M. Distúrbios da fala: diagnóstico e tratamento. Rio de Janeiro: Revinter, 1997.

MOTA, V. A.; GUEDES, Z. C. F. Análise da fala de crianças pré-escolares pertencentes à escola da rede pública no município de São Paulo. R. Fono Atual., São Paulo, v. 3, n. 13, p. 48-56, jul.-set. 2000.

MOTTA, A. R., MARTINS, C. D.; PEGO, M. F.; OLIVEIRA, R. S.; FERREIRA, S. C. Estudo comparativo entre as idades descritas por Teixeira, Yavas e Wertzner para supressão dos processos fonológicos. In: CONGRESSO INTERNACIONAL, 5., CONGRESSO BRASILEIRO, 11., ENCONTRO CEARENSE DE FONOAUDIOLOGIA, 1., 2003, Fortaleza. Anais... São Paulo: Sociedade Brasileira de Fonoaudiologia, out. 2003. p. 629. CD-ROM.

OLIVEIRA, M. M.; WERTZNER, H. Estudo do distúrbio fonológico em crianças. R. Soc. Bras. Fonoaudiol., São Paulo, v. 7, p. 68-75, 2000.

PAGAN, L. O.; WERTZNER, H. F. Intervenção no distúrbio fonológico por meio dos pares mínimos com oposição máxima. Pró-Fono R. Atual. Cient., Barueri (SP), v. 14, n. 3, p. 313-324, set.-dez. 2002.

PEREIRA, M. M. B.; BIANCHINI, E. B. G.; CARVALHO, G. G. T.; JARDIM, Z. M. G. Investigação da ocorrência e caracterização de distorções do [s] em crianças de 3 a 10 anos. R. Soc. Bras. Fonoaudiol., São Paulo, v. 8, n. 1, p. 10-17, jun. 2003.
PEREIRA, J. R.; REIS, A. M.; MAGALHÃES, Z. Neuroanatomia funcional: anatomia das áreas activáveis nos usuais paradigmas em ressonância magnética funcional. Acta Méd. Portug., Lisboa, v. 16, n. 3, p. 106-117, may-jun. 2003.

RIGATTI, A. P.; ROCHELE, P. F.; RAMOS, A. P. F. Aquisição normal e desviante do rótico alveolar simples em dois dialetos do português brasileiro. Pró-Fono R. Atual. Cient., Carapicuíba (SP), v. 13, n. 2, p. 157-164, set. 2001.

RODRIGUES, N. Neurolingüística dos distúrbios da fala. 3. ed. São Paulo: Cortez EDUC, 1999.

SANTOS, L. K.; ÁVILA, C. R. B.; CECHELLA, C.; MORAIS, Z. R. Ocorrência de alterações de fala, do sistema sensoriomotor oral e de hábitos orais em crianças préescolares e escolares da $1^{a}$ série do primeiro grau. PróFono R. Atual. Cient., Carapicuíba (SP), v. 12, n. 2, p. 93101, set. 2000.

SHRIBERG, L. D.; ARAM, D. M.; KWIATKOWSKI, J. Developmental apraxia of speech: I, descriptive and theoretical perspectives. J. Speech Lang. Hear. Res., Rockville, v. 0, n. 2, p. 273-285, apr. 1997.

TOMÉ, M. C.; BECKER, C. N.; FARIAS, S. R.; AMORIM, M.; MARCHIORI, S. Relação entre sigmatismo anterior e alterações oclusais em crianças de 03 a 06 anos. J. Bras. Fonoaudiol., Curitiba, v. 2, n. 8, p. 261, jul.-set. 2001.

TOMÉ, M. C.; FARIAS, S. R.; MARCHIORI, S.; SCHIMITT, B. E. Ceceio interdental e alterações oclusais em crianças de 03 a 06 anos. Pró-Fono R. Atual. Cient., Barueri (SP), v. 16, n. 1, p. 19-30, jan.-abr. 2004.

VON ATZINGEN, B. S. Apraxia do desenvolvimento: aspectos diagnósticos. Pró-Fono R. Atual. Cient., Carapicuíba (SP), v. 14, n. 1, p. 39-50, jan.-abr. 2002.

WERTZNER, H. F.; OLIVEIRA, M. M. Semelhanças entre os sujeitos com distúrbio fonológico. Pró-Fono R. Atual. Cient., Barueri (SP), v. 14, n. 2, p. 43-152, maio-ago. 2002.

WERTZNER, H. F.; PATAH, L. K. Análise acústica do /s / e / S / em crianças com distúrbio fonológico. J. Bras. Fonoaudiol., Curitiba, v. 2, n. 7, p. 169-174, abr.-jun. 2001.

WERTZNER, H. F.; GALEA, D. E. S.; ALMEIDA, R. C. Uso do processo fonológico de simplificação de velar em crianças de 2,1 a 3,0 anos de idade. J. Bras. Fonoaudiol., Curitiba, v. 2, n. 8, p. 233-238, 2001 a.

WERTZNER, H. F.; AMARO, L.; TERAMOTO, S. S. Determinant factors of severety ranting of phonological disorders. Pró-Fono R. Atual Cient., Barueri (SP), v. 16, n. 2, p. 139-150, maio-ago. 2004.

WERTZNER, H. F.; HERRERO, S. F.; IDERIHA, P.; PIRES, S. C. F. Classificação do distúrbio fonológico por meio de duas medidas de análise: porcentagem de consoantes corretas (PCC) e índice de ocorrência dos processos (PDI). Pró-Fono R. Atual. Cient., Carapicuíba (SP), v. 13, n. 1, p. 90-97, mar. 2001b.

WOHLERT, A. B.; SMITH, A. Development change in variability of lip muscle activity during speech. J. Speech Lang. Hear. Res., Rockville, v. 45, n. 6, p. 1077-1087, dec. 2002.

YAVAS, M.; HERNANDORENA, C. L. M.; LAMPRECHT, R. R. Avaliação fonológica da criança: reeducação e terapia. Porto Alegre: Artes Médicas, 1991. 